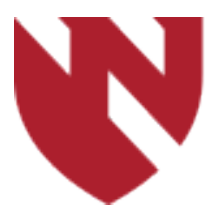

September 2020

\title{
A Beer League Degloving
}

Hannah Hornsby

University of Nebraska Medical Center

Hudson McGinnis

University of Nebraska Medical Center

T. Jason Meredith

University of Nebraska Medical Center

Tell us how you used this information in this short survey.

Follow this and additional works at: https://digitalcommons.unmc.edu/gmerj

Part of the Higher Education Commons, and the Medicine and Health Sciences Commons

\section{Recommended Citation}

Hornsby, H., McGinnis, H., , Meredith, T. A Beer League Degloving. Graduate Medical Education Research Journal. 2020 Sep 29; 2(1).

https://digitalcommons.unmc.edu/gmerj/vol2/iss1/55

This Conference Proceeding is brought to you for free and open access by DigitalCommons@UNMC. It has been accepted for inclusion in Graduate Medical Education Research Journal by an authorized editor of DigitalCommons@UNMC. For more information, please contact digitalcommons@unmc.edu. 


\section{A Beer League Degloving}

Creative Commons License

(c) (i) ()

This work is licensed under a Creative Commons Attribution-Noncommercial-No Derivative Works 4.0 License. 


\section{The Incidence, Prevalence and Burden of Gout in the Veterans Health Administration}

Lindsay Helget ${ }^{1}$, Bryant England ${ }^{1}$, Punyasha Roul ${ }^{1}$, Harlan Sayles ${ }^{2}$, Alison Petro ${ }^{1}$, Kaleb Michaud ${ }^{1}$, Ted Mikuls ${ }^{1}$

${ }^{1}$ University of Nebraska Medical Center, Department of Internal Medicine, Division of Rheumatology

${ }^{2}$ University of Nebraska Medical Center, College of Public Health, Department of Biostatistics

Mentor: Ted Mikuls and Bryant England

Program: Internal Medicine, Division of Rheumatology

Type: Original Research

Background: To determine the prevalence, incidence, and burden of gout in the Veterans Health Administration (VHA) from 20052014.

Methods: We used national VHA data from 1/1999-12/2014 to determine the annual incidence and prevalence of gout in the VHA. Gout burden to the VHA was determined by the proportion of patients with an encounter related to gout. Rates of urate lowering therapy (ULT) and opiate use were determined annually. Characteristics of those with and without gout were compared using 2014 data.

Results: From 2005 to 2014, gout prevalence in the VHA increased from $4.2 \%$ to $5.8 \%$ while disease incidence ranged from 5.8 to 7.4 cases per 1000 patient-years. Gout prevalence was highest among men, older patients, and non-Hispanic blacks. During 2014, $4.0 \%$ of all inpatient or outpatient encounters and $1.3 \%$ of hospitalizations were gout-related. ULT administration remained stable over the ten-year period, with $46 \%$ of gout patients receiving ULT in 2014. In contrast, $16.4 \%$ of prevalent gout patients were receiving a weak opioid in 2014, nearly doubling the prescription rate of weak opioids in 2005 while the use of stronger opioids did not change significantly over this period. Patients with gout had greater comorbidity and healthcare utilization than patients without gout.

Conclusion: The burden posed by gout in the VHA is considerable and increased between 2005 and 2014. While the use of ULT has remained stable, the use of opioid therapy has increased among patients with gout.

https://doi.org/10.32873/unmc.dc.gmerj.2.1.052

\section{A Beer League Degloving Hannah Hornsby ${ }^{1}$, Hudson McGinnis ${ }^{1}$, T. Jason Meredith ${ }^{1}$ \\ ${ }^{1}$ University of Nebraska Medical Center, Department of Family Medicine}

Program: Family Medicine

Type: Case Report

Introduction: Morel-Lavallée lesions are rare, closed degloving injuries between the skin and underlying fascia that creates a fluid collection within the pre-fascial plane. Common causes are high-energy, blunt force trauma and crush injuries.

Case: A 29-year-old male who presented with left thigh pain, swelling and ecchymosis after attempting a "pop-up" slide into third base during a softball game. His foot caught the base and he flipped forward on his extended knee. He had immediate swelling and pain but ambulated off the field. In clinic two days later, he reported increased swelling and bruising but denied loss of strength or instability. Exam showed thigh swelling and large ecchymosis throughout the thigh and into the knee and upper shin. He had reduced flexion but preserved extension. MRI demonstrated a large anteromedial thigh fluid collection, consistent with large MorelLavallée lesion. He successfully treated conservatively with tight compression and activity restriction. With serial follow-ups and evaluation with sports medicine, the patient continued to improve.
Discussion: Prompt compressive therapy obviates complications of infection, fluid expansion and tissue necrosis, which when present require more invasive interventions. With small, acute lesions, compression alone often suffices for resolution, however, larger lesions can require percutaneous drainage, sclerodesis or debridement. Our case highlights the need to consider Morel Lavallée lesions in expanding soft tissue injuries, even when not associated with high velocities.

https://doi.org/10.32873/unmc.dc.gmerj.2.1.053

\section{The Effect of Weather on Orthopedic Injury Presentation to the Emergency Department Ryan Houghton ${ }^{1}$, Liz Lyden', Aaron Barksdale ${ }^{1}$ \\ ${ }^{1}$ University of Nebraska Medical Center, Department of Emergency Medicine}

Mentor: Aaron Barksdale

Program: Emergency Medicine

Type: Original Research

Background: Predicting patient flow and presentation in the emergency department (ED) is difficult. Chief complaints vary and often appear random from an anecdotal perspective. Prior studies attempting to correlate weather conditions with orthopedic injuries have been conflicting. The purpose of this study was to explore associations between weather patterns and orthopedic presentations to the UNMC ED.
Methods: Retrospective chart review was conducted at a tertiary academic hospital with 64,000 annual ED visits. Utilizing electronic medical records, all patients visiting the ED between $9 / 1 / 2012$ to $4 / 30 / 2019$ were included. ICD10 codes identified patients diagnosed with fractures of upper (distal forearm through wrist) and lower (proximal femur and hip) extremities. Daily weather patterns were obtained through the National Oceanic and Atmospheric Administration, specifically daily temperature, amount and type of precipitation (none, rain/melted snow, ice/snow). Logistic regression was used to determine if weather conditions were predictive of fractures. Results are displayed as odds ratios and 95\% confidence intervals. $\mathrm{P}<0.05$ was considered statistically significant.

Results: Over an 80-month period 373,409 patients were included, with 4,416 fractures identified. Overall, there was a statistically significant association between snow/ice and fractures $(p<0.0001)$. Specifically, an increased risk of upper extremity fracture (OR 1.47, CI 1.28-1.69) and lower extremity fracture (OR 1.25, CI 1.02-1.53). The risk of upper extremity fracture further increased when snow/ice accumulation was $>3$ inches (OR 2.64, CI 1.91-3.65). Rain/melted snow was not associated with increased fractures. 